\title{
Bioremediation of Hydrocarbon Contaminated Soil: Assessment of Compost Manure and Organic Soap
}

\author{
${ }^{1}$ Akpokodje, O. I. and ${ }^{2}$ Uguru, $\mathbf{H}$. \\ ${ }^{1}$ Department of Civil Engineering Technology, Delta State Polytechnic, Ozoro, Nigeria \\ ${ }^{2}$ Department of Agricultural and Bio-environmental Engineering Technology, Delta State Polytechnic, \\ Ozoro, Nigeria \\ erobo2011@gmail.com
}

\begin{abstract}
This study was carried out to investigate the effect of compost manure and organic soap on hydrocarbon degradation in petroleum products contaminated soil. $10 \mathrm{~kg}$ of top soil collected at a depth of $0-20 \mathrm{~cm}$, air dried and sieved, were poured into plastic containers. The soil samples were pounded with $1 \mathrm{~L}$ of spent engine oil, $1 \mathrm{~L}$ of kerosene, $1 \mathrm{~L}$ of petrol and $1 \mathrm{~L}$ of diesel daily for five days. The containers were placed under natural environmental conditions for three weeks to enable full acclimatization of the petroleum products with the soil. A completely randomized design comprising T1 (Polluted soil without treatment 'control'); T2 (10 kg contaminated soil + 500 g organic soap); T3 (10 kg contaminated soil + 500 g compost manure); and T4 (10 kg contaminated soil + 500 g compost manure +500 g organic soap) was used for this study. Some physical characteristics (soil porosity and specific gravity) and Total Hydrocarbon Content (THC) of the soil samples were tested for, after the full acclimatization of the soil samples, and at the end of the 10 week experimental period, in accordance with standard methods. Results of the study showed that addition of the compost manure and organic soap to the contaminated soil samples significantly ( $p$ $\leqslant 0.05$ ) degraded the THC, and improved the soil physical characteristics. The result showed that the combination of compost manure and organic soap gave the best remediation result (from $957.21 \mathrm{mg} / \mathrm{kg}$ to $154.36 \mathrm{mg} / \mathrm{kg}$ ), followed by organic soap (from $957.21 \mathrm{mg} / \mathrm{kg}$ to $203.61 \mathrm{mg} / \mathrm{kg}$ ), and then compost manure (from $957.21 \mathrm{mg} / \mathrm{kg}$ to $262.03 \mathrm{mg} / \mathrm{kg}$ ). At the end of the experimental period, vegetative growth was observed in the treated soil samples; whereas, in the control soil samples vegetative growth was absent. Results obtained from this study have shown that amending petroleum products contaminated soils with compost manure and organic soap will enhance remediation of petroleum products contaminated sites.
\end{abstract}

Keywords: Petroleum products, compost manure, organic soap, THC, remediation

\section{Introduction}

Environmental pollution has become a problem affecting developed, developing and under-developed countries, and it is assuming a great threat to the well-being of all life forms [1]. Recently oil exploration and exploitation in Nigeria has taken a new dimension. Nigeria has the recorded largest natural gas reserve and the second largest oil reserve in Africa. Ghosh and Singh [2] reported oil exploration and exploitation, accidental and process spillage, sabotage among others, as major factors responsible for the 
Akpokodje, O. I. and Uguru, H.; Bioremediation of Hydrocarbon Contaminated Soil: Assessment of Compost Manure and Organic Soap, Transactions on Machine Learning and Artificial Intelligence, Volume 7 No 5 October, (2019); pp: 13-23

environmental pollution from petroleum products. Petroleum is a complex mixture, containing significant amount of saturated alkanes, alkynes, alkenes, napthenes, highly toxic polycyclic aromatic hydrocarbons, and some heavy metals [3]. Petroleum compounds are toxic to all forms of life, and have adverse effect on the soil's physical characteristics and biochemical properties [4]. Petroleum hydrocarbon contamination has become a critical environmental issue due to its immobilization and accumulation [56]; and is now seriously affecting the safety of ecosystems and human health [4; 7]. Peng et al. [8] observed in their study that population of microorganisms in any soil was highly dependent on the level of petroleum hydrocarbons contaminants in the soil.

Remediation of petroleum products contaminated soils has become a great concern worldwide, due to their (petroleum products) reported adverse effects on the environment. Remediation of petroleumcontaminated soils could be achieved by either physical/mechanical (e.g excavation, burning); chemical (detergent, surfactant, degreaser), plants (phytoremediation) and biological (bioremediation) methods $[4 ; 9]$. Any remediation method adopted for the cleanup of a contaminated site depends on how suitable or efficient the method is with prospect to the prevailing site conditions. However, most of these methods have some drawbacks in completely remediating petroleum hydrocarbon contaminated soil [10]. Detailed assessment of the advantages and disadvantages of various remediation techniques are reported by United States Environmental Protection Agency [11]. The harmful effects of oil in different environments, has led to the need to develop simple adoptable remediation techniques for petroleum polluted sites using different simple and affordable methods, which may include physical, chemical and biological processes [9].

Phytoremediation is the use of plants and/or associated microorganisms to remove contain or render harmful material(s) harmless [12-13]. Phytoremediation has been shown to be effective for broad range of contaminants like petroleum products, cyanide, heavy metals, etc. Plants used for phytoremediation should be tolerant to the climatic and soil conditions of the contaminated areas [13-14]. Karenlampi et al. [15] reported four main characteristics that can make a plant suitable for the phytoremediation of contaminated soils. These factors are: the plant's ability to accumulate the extracted contaminant; the plant should be tolerant enough not only to survive in polluted soils, but to carry pollutants within their shoots; the plant should be fast growing with an amplified ability to accumulate toxins; and the plant should be easily harvestable for simple disposal [16].

Bioaugmentation is the applications of indigenous or allochthonous wide type or genetically modified microorganisms to polluted hazardous waste sites in order to accelerate the removal of undesired compounds [17-18]. Generally, bioremediation technologies can be classified as in situ or ex situ. In situ bioremediation involves treating the contaminated material at the site while ex situ involves the removal of the contaminated material to be treated elsewhere [25]. Tanee and Jude [19] reported that detergent and sawdust amendment were able to degrade the THC of petroleum contaminated soil to significant level. Some of the organic products employed are sewage sludge, cow dung, poultry waste, compost manure etc. Okolo et al. [20] observed increment in the degradation of crude oil in soil samples augmented with poultry manure; as it helps the plants to release root exudates which helped to break down the crude oil. Reference [21] suggested that the use of chicken manure to stimulate crude oil degradation in the soil could be one of the several sought-after environmentally friendly ways of combating petroleum hydrocarbon pollution in the natural ecosystem. In addition, [22] investigated the 
bioremediation potentials of poultry manure and cow dung on crude oil polluted soil samples. They observed that the application of poultry manure and cow dung significantly degraded the petroleum hydrocarbons in the soils. Their results further revealed that poultry manure showed superiority over cow dung in the remediation of crude oil polluted soils.

However, studies on bioremediation of petroleum products contaminated soils in Nigeria is still in the preliminary stage. Therefore, the main objective of this study was to evaluate the efficiency of organic soap formulated from oil palm bunch waste and compost manure in degrading hydrocarbons in petroleum products contaminated soil, with the ultimate goal of eliminating some toxic substances and improving the state of the soil, such as the Total Hydrocarbon Content (THC) in the soil.

\section{Materials and Methods}

\subsection{Source of material}

The spent engine oil was purchased from a mechanic workshop located at Oleh, Delta State, Nigeria; while the petrol, diesel and kerosene were obtained from a filling station located at Ozoro, Delta State, Nigeria.

\subsection{Soil sample collection and contamination}

Top soil $(0-20 \mathrm{~cm})$ depth was collected from the irrigation station of Delta State Polytechnic, Ozoro, Nigeria. The collected soil sample was air dried in the laboratory at ambient temperature, and later sieved with a $2 \mathrm{~mm}$ stainless steel sieve to remove all stones and other debris. The soil samples were contaminated in accordance with standard methods as stated by [13]. $10 \mathrm{~kg}$ of the soil was weighed into each plastic containers perforated at the bottom and artificially polluted with $1 \mathrm{~L}$ of spent engine oil, $1 \mathrm{~L}$ of kerosene, $1 \mathrm{~L}$ of petrol and $1 \mathrm{~L}$ of diesel daily for five days. The set up was allowed to stand for three weeks for full acclimatization of the petroleum products with the soil under natural environmental conditions in an open space.

\subsection{Organic soap preparation}

Palm fruit bunch waste was collected from the palm oil mill of Delta State Polytechnic, Ozoro, Nigeria. The waste was sundried and burnt into ashes. After that, the ashes were dissolved in distill water to obtain a heterogeneous solution. The solution was filtered with whatman No1 filter paper, and the filtrate obtained evaporated to dryness. Crystals recovered from the dried solution was used to prepare the organic soap according to standard method.

\subsection{Composting of the compost manure}

Wood sawdust was obtained from timber sawmill located at Ozoro, Delta state, Nigeria, while the poultry droppings and cattle dungs were obtained from the animal farm situated at Delta State Polytechnic, Ozoro. The three constituents (saw dust, poultry waste and cattle dung) were composed using a mixing ratio of 10\%:45\%:45\% (volume to volume), and composed using the passively aerated static pile method for a period of three months.

\subsection{Remediation set up}

The concentration levels (amounts) of compost manure and organic soap used as amendment in the remediation are presented in Table 1. 
Akpokodje, O. I. and Uguru, H.; Bioremediation of Hydrocarbon Contaminated Soil: Assessment of Compost Manure and Organic Soap, Transactions on Machine Learning and Artificial Intelligence, Volume 7 No 5 October,

Table 1: Experimental set up

\begin{tabular}{ll}
\hline Treatment & Concentration \\
\hline T1 & $10 \mathrm{~kg}$ contaminated soil (Control) \\
\hline T2 & $\begin{array}{l}10 \mathrm{~kg} \text { contaminated soil }+500 \mathrm{~g} \\
\text { compost manure }\end{array}$ \\
\hline $\mathrm{T} 3$ & $\begin{array}{l}10 \mathrm{~kg} \text { contaminated soil }+500 \mathrm{~g} \\
\text { organic soap }\end{array}$ \\
\hline T4 & $10 \mathrm{~kg}$ contaminated soil $+500 \mathrm{~g}$ \\
& compost manure $+500 \mathrm{~g}$ organic soap \\
\hline
\end{tabular}

The remediation set up was laid out in a completely randomized design (CRD) with three replicates.

In the compost manure treatment, the compost manure and the soil sample were thoroughly mixed to obtain a homogeneity mixture. While in the organic soap treatment, the organic soap was divided into two equal parts. One part was thoroughly mixed with the soil sample to obtain a homogeneity mixture; while the other part was dissolved in one litre of distil water to form a homogeneity mixture, before it was poured gently into plastic container containing the soil sample. All the plastic containers (control and treated) were placed in an open space, under atmospheric conductions (rainfall, sunlight, relative humidity, temperature, dew, etc.) for an experimental period of ten weeks. At the end of the ten weeks, another round of physiochemical and THC tests were carried out on the soil samples.

\subsection{Determination of the Total Hydrocarbon content}

The Soxhlet Extraction Method [23] was used for the determination of Total Hydrocarbon Content (THC) of the soil samples.

\subsection{Soil physical characteristics analysis}

The following physical characteristics analysis (porosity and specific gravity) were carried out on the contaminated (after full acclimatization period), and the remediated soil samples. The soil porosity and specific gravity were determined by using standard methods [24].

\subsection{Statistical evaluation}

Data obtained from this study was analyzed using Analysis of variance (ANOVA) according to SPSS data analysis package (2018 version). The mean separation of parameters investigated was done by using Duncan's Multiple Range tests at 95\% confidence level.

\section{Results and Discussion}

\subsection{Physicochemical analyses of the compost manure and organic soap}

The physicochemical properties of the compost manure and organic soap used for the bioremediation experiment are presented in Table 2 . 
Table 2: Physicochemical Properties of compost manure and organic soap used for bioremediation

\begin{tabular}{lll}
\hline Parameter & $\begin{array}{l}\text { Compost } \\
\text { manure }\end{array}$ & $\begin{array}{l}\text { Organic } \\
\text { soap }\end{array}$ \\
\hline $\mathrm{pH}$ & 8.3 & 9.1 \\
Total nitrogen $(\mathrm{mg} / \mathrm{kg})$ & 9.23 & 5.61 \\
Phosphorus $(\mathrm{mg} / \mathrm{kg})$ & 427.91 & 3220.56 \\
Potassium $(\mathrm{mg} / \mathrm{kg})$ & 1687.58 & 4951.44 \\
Moisture $(\%)$ & 13.09 & 21.56 \\
\hline
\end{tabular}

The analysis of variance (ANOVA) results presented in Table 3 showed that the various treatment methods had significant effect on all the parameters investigated in this study. The results showed that Treatment 4 (contaminated soil + compost manure + organic soap) had the highest remediation impact on the contaminated soil, followed by Treatment 3 (contaminated soil + organic soap), and then Treatment 2 (contaminated soil + compost manure) while Treatment 1 (contaminated soil 'control') had the least remediation effect.

Table 3: Analysis of variance of treatment methods on the THC, porosity and specific gravity of contaminated soil

\begin{tabular}{lll}
\hline Source of vibration & df & Sig \\
\hline THC & 4 & $5.64 \mathrm{E}-13$ \\
Specific gravity & 4 & $2.65 \mathrm{E}-08$ \\
Porosity & 4 & $2.63 \mathrm{E}-07$ \\
\hline
\end{tabular}

\subsection{Bioremediation of the THC}

The result of biodegradation of THC in the petroleum products contaminated soils at the end of the experimental period is shown in Figure 1. At the end of the 10 week period, the contaminated soil samples treated with the combination of $500 \mathrm{~g}$ compost manure and $500 \mathrm{~g}$ organic soap (T4) gave the best result with $83 \%$ biodegradation, followed by the soil samples treated with organic soap (T3) with $79 \%$ biodegradation, and then the soil treated with compost manure (T2) with $72 \%$ biodegradation, when compared to the un-treated 'control' soil that showed $29 \%$ biodegradation of the THC. The differences in the results obtained might be due to different nutrient concentrations of the treatment materials used. The biodegradation potentials of the treatment materials (compost manure and organic soap) can also be attributed to the high absorbent material present (from the sawdust) in the compost manure; and the demulsification effect of the organic soap.

During the bioremediation process, the compost manure provides nutrients that will energize the hydrocarbons degrading microorganisms. Organic nutrients stimulate degradation capabilities of the indigenous microorganisms thus allowing the microorganisms to break down the organic pollutants at a faster rate [26]. Apart from the demulsification of petroleum products by the organic soap during the bioremediation process, the organic soap provides suitable environment for the soil microorganisms, by supplying them some essential nutrients (Nitrogen, potassium and phosphorus). Potassium, phosphorus and nitrogen are some of the chief constituents of the organic soap (Table 2). Nitrogen and phosphorus compounds help to remediate oil polluted soil, as they accelerate the biodegradation of the petroleum hydrocarbon in the soil [27]. Similar results were observed in hydrocarbon contaminated 
Akpokodje, O. I. and Uguru, H.; Bioremediation of Hydrocarbon Contaminated Soil: Assessment of Compost Manure and Organic Soap, Transactions on Machine Learning and Artificial Intelligence, Volume 7 No 5 October, (2019); pp: 13-23

soils amended with poultry and pig manure compost [28-29]. Ogboghodo et al. [21] observed that chicken manure was able to degrade hydrocarbons in crude oil contaminated soil by $75 \%$ within two weeks, due to their high nitrogen content.

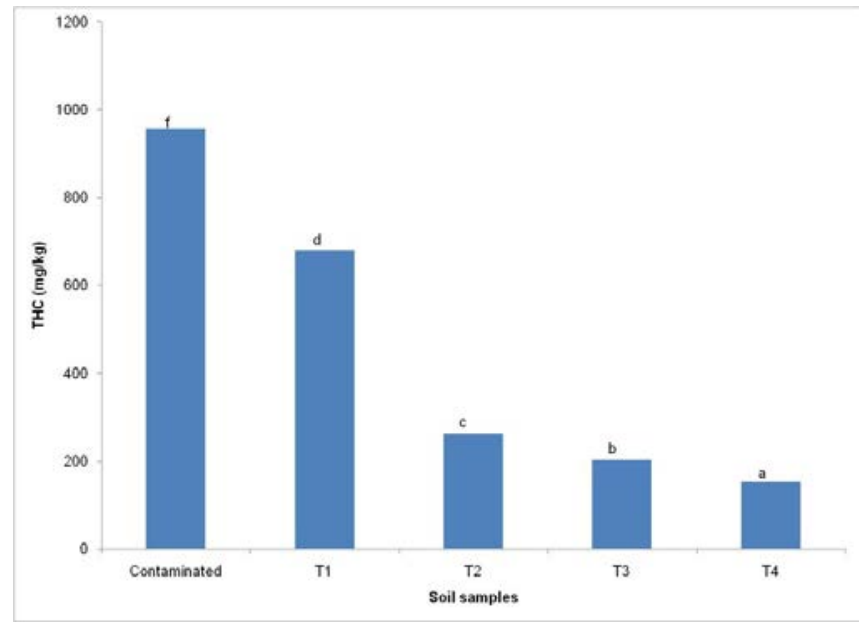

Figure 1: Biodegradation of THC in a contaminated soil using compost manure and organic soap.

Columns with the same common latter are not significantly different $(p \leqslant 0.05)$ according to Duncan' $s$ multiple ranges test

\subsection{Soil physical characteristics}

\section{Porosity}

Apart from the degradation of the THC in the soil samples at the end of the experimental period, the results presented in Figures 2 and 3 showed that the treatments significantly $(p \leqslant 0.05)$ influenced the physical characteristics of the contaminated soil samples. The results (Figure 2) showed that the combination of the organic soap and compost manure had the greatest bioremediation effect on the soil porosity. Combination of the organic soap and compost manure treatment improved the soil porosity from $15.33 \%$ to $32.40 \%$; the organic soap improved the porosity from $15.33 \%$ to $29.01 \%$; while and the compost mature improved the soil porosity from $15.33 \%$ to $26 \%$, within the 10 week experimental period. There was no significant $(p \leqslant 0.05$ ) difference between the porosity of the soil sample treated with organic soap, when compared with the soil sample treated with compost manure (Figure 2). As seen in Figure 2, the porosity of the control soil increased significantly $(p \leqslant 0.05)$, when compared to the initial contaminated soil samples. The significant improvement in the control soil samples porosity can be attributed to the leaching of the hydrocarbons during downpour, and evaporation of some of the volatile hydrocarbons, since the experimental set up were kept in the open space, exposed to environmental conditions. Petroleum products blocked soil air pores (reduced the porosity), thereby lowering the water holding capacity and aeration in the soil [30]. This deprived the soil its oxygen and water holding abilities, which are necessary for plant and microbial growth. 


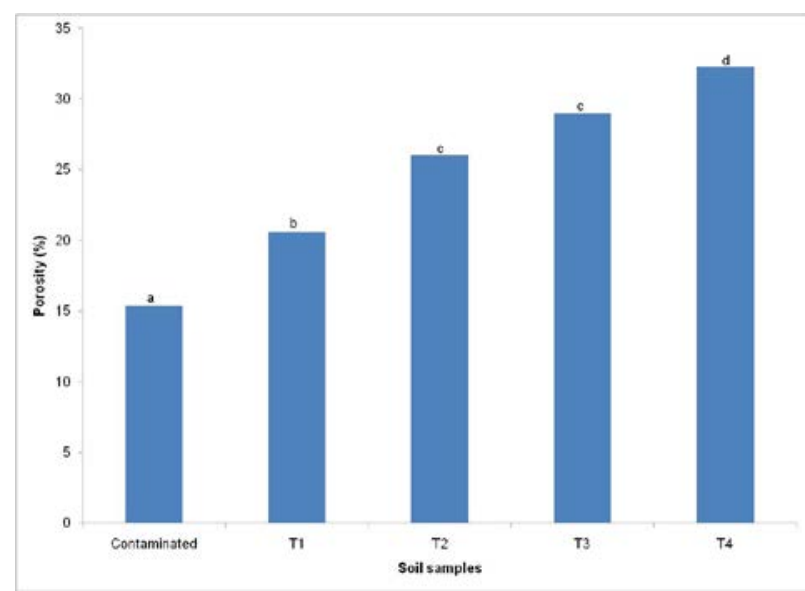

Figure 2: Effect of compost manure and organic soap on the porosity of the contaminated soil samples

Columns with the same common latter are not significantly different $(p \leqslant 0.05)$ according to Duncan' $s$ multiple ranges test

\section{Specific gravity}

The results presented in Figure 3 showed that the treatment combination of organic soap and compost manure had the statistical highest remediation effect on the soil specific gravity. The mean specific gravity of the soil samples increased from 1.59 to 2.18, after treatment with the combination of organic soap and compost manure, within the 10 week experimental period. Organic soap was able to increase the specific gravity of the soil from 1.59 to 2.04; while and the compost manure increased the soil specific gravity from 1.59 to 1.90 within the 10 week experimental period (Figure 3). As shown in the chart presented in Figure 3 , there was no significant $(p \leqslant 0.05)$ difference between the specific gravity of the contaminated soil and the control soil samples at the end of the experimental period. Similar results were reported by [31-32]. Amadi et al. [32] stated that high hydrocarbon content of soils may affect the physicochemical properties of the soil which may in turn affect the agricultural potentials and productivities of such soils.

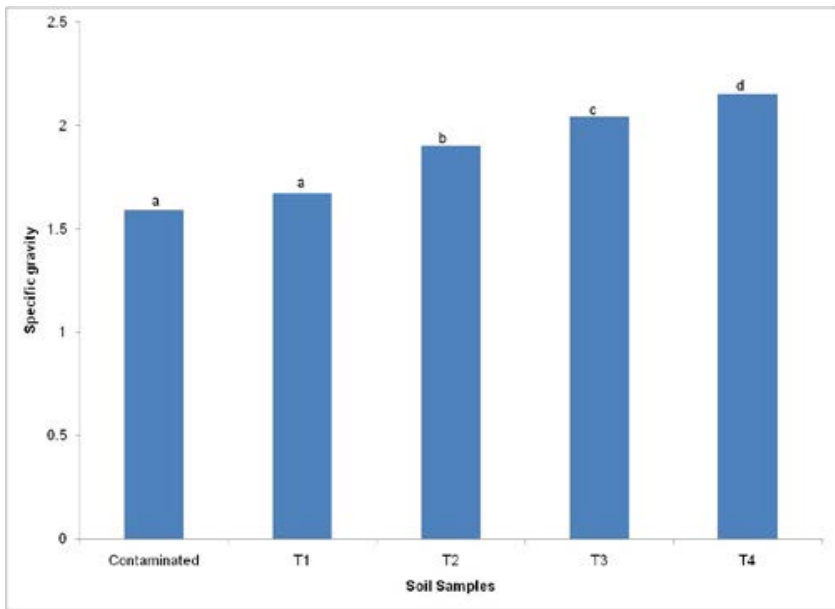

Figure 3: Effect of compost manure and organic soap on the specific gravity of the contaminated soil samples 
Akpokodje, O. I. and Uguru, H.; Bioremediation of Hydrocarbon Contaminated Soil: Assessment of Compost Manure and Organic Soap, Transactions on Machine Learning and Artificial Intelligence, Volume 7 No 5 October, (2019); pp: 13-23

Columns with the same common latter are not significantly different $(p \leqslant 0.05)$ according to Duncan' $s$ multiple ranges test

\subsection{Vegetative growth}

As shown in Figure 4, vegetative growth was observed in the treated soil samples, when compared to the untreated soil sample which showed no form of plant life. Plants growing on the treated soil samples will further aid the degradation of the THC in the soil and improve the soil's physical characteristics, as they have the ability to degrade petroleum products in the soil and in water bodies. Plants root exudates help to degrade toxic organic chemicals and act as substrates for bacteria in the soil, which improves the plants phytoremediation potential $[4 ; 33]$. Absence of vegetative growth in the control soil sample confirms the toxicity of petroleum products to soil microbial activity required for effective degradation [34]. Vegetative growth found in the treated soil was stimulated by the compost manure used as the treatment materials. Merkl et al. [35] reported higher degradation of petroleum hydrocarbon in vegetated soils compared to non-vegetated soil. These results are similar to results from previous researchers. Okolo et al. [20] observed degradation of crude oil in soil amended with poultry manure; [36] reported that organic manures have the potential of degrading hydrocarbon in contaminated soils by increasing the total heterotrophic microbial growth and activity. The extent poultry manure degrades crude oil in contaminated soil depends on the presence of other soil amendments [20]. Addition of compost manure helps to improve the physicochemical properties of petroleum products contaminated soils; hence, enhancing the remediation of these contaminants and improving oil biodegradation rates.

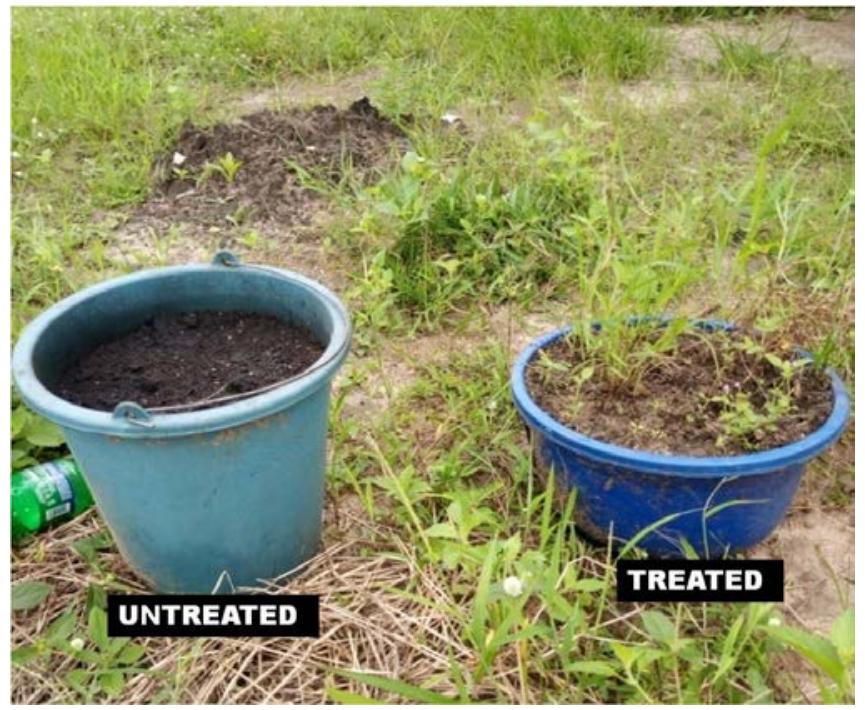

Figure 4: Effect of compost manure and organic soap on the vegetative growth of the contaminated soil samples

\section{Conclusion}

This study was carried to evaluate the bioremediation potentials of compost manure and organic soap. Top soil samples were contaminated mixture of petroleum products, and remediated for 10 weeks. The results of the study showed that the contaminated soil treated with combination of compost manure and organic soap recorded the highest hydrocarbon biodegradation of $83 \%$, when compared to the single treatment of compost manure (72\%) or organic soap (79\%). The different results obtained were due to 
different nutrients concentration of the treatment materials. In terms of the soil physical characteristics, results obtained from the study, that both treatment materials significantly improved the soil porosity and specific gravity. The combination of the organic soap and compost manure had the greatest bioremediation effect on the soil porosity and specific gravity. At the end of the experimental period, vegetative growth was found on the treated soil samples; whereas, vegetative growth was absent in the control soil samples. Results obtained from this study further showed that utilization of organic waste materials in the bioremediation of contaminated soils. However, more researches involving other organic waste materials are crucial in order to identify suitable organic waste materials to be used in bioremediation of hydrocarbon compounds.

\section{REFERENCES}

[1] Suresh, B. and Ravishankar, G. A. (2004). Phytoremediation-A novel and promising approach for environmental cleanup. Critical Reviews in Biotechnology, 24, (2-3): 97-124.

[2] Ghosh, M. and Singh, S.P. (2005). A review on phytoremediation of heavy metals and utilization of its by products. Applied Ecology and Environmental Research, 3: 1-18.

[3] Abha, S. and Singh, C.S. (2010). Hydrocarbon pollution: Effects on living organisms, remediation of contaminated environments, and effects of heavy metals co-contamination on bioremediation. Introduction to Enhanced Oil Recovery (EOR) Processes and Bioremediation of Oil- Contaminated Sites. Dr. Laura Romero-Zerón (Ed.)

[4] Akpokodje O. I. and Uguru, H (2019). Phytoremediation of petroleum products contaminated soil. Archives of Current Research International, 18 (1): 1-8.

[5] Martínez-Jerónimo, F., Cruz-Cisneros, J.L. and García-Hernández, L. (2008). A comparison of the response of Simocephalus mixtus (Cladocera) and Daphnia magna to contaminated freshwater sediments. Ecotoxicol. Environ. Saf., 71:26-31.

6] Wang, X. Y., Feng, J. and Zhao, J. M. (2010). Effects of crude oil residuals on soil chemical properties in oil sites, Momoge Wetland, China. Environ. Monit. Assess., 161: 271-280.

[7] Liste, H..H., and Felgentreu, D. ( 2006). Crop growth, culturable bacteria, and degradation of petroleum hydrocarbons (PHCs) in a long-term contaminated field soil. Appl. Soil Ecol., 31: 4352

[8] Peng, S., Zhou, Q., Cai, Z. and Zhang, Z (2009). Phytoremediation of petroleum contaminated soils by Mirabilis jalapa L. in a greenhouse plot experiment. J. Hazard. Mater. 168:1490-1496.

[9] Okoh, A. I. (2006). Biodegradation alternative in the clean up of petroleum hydrocarbon pollutants. A review. Biotechnology and Molecular Biology, 1 (2): 38-50.

[10] Kumar, B. L. and Gopal, D. S. (2015). Effective role of indigenous microorganisms for sustainable environment. Biotech., 5(6): 867-876.

[11] United States Environmental Protection Agency (USEPA). (2001). Ground Water Issue Phytoremediation of Contaminated Soil and Ground Water at Hazardous Waste Sites, Office of Solid Waste and Emergency Response Office of Research and Development EPA/540/S-01/500, 
Akpokodje, O. I. and Uguru, H.; Bioremediation of Hydrocarbon Contaminated Soil: Assessment of Compost Manure and Organic Soap, Transactions on Machine Learning and Artificial Intelligence, Volume 7 No 5 October,

(2019); pp: 13-23

National Risk Management Research Laboratory Subsurface Protection and Remediation Division Robert S. Kerr Environmental Research Center Ada, Oklahoma Superfund Technology Support Center for Ground Water, ManTech Environmental Research Services Corporation, OK 74820.

[12] Merkl, N. (2005) Phytoremediation of petroleum-contaminated soil. Margraf Publisher Weikershim, 125

[13] Akpokodje, O. I, Uguru, H. and Esegbuyota, D. (2019) Evaluation of phytoremediation potentials of different plants' varieties in petroleum products polluted soil. Global Journal of Earth and Environmental Science. 4(3):41-46

[14] Pivetz, B.E. (2001). Phytoremediation of Contaminated Soil and Ground water at Hazardous Waste Sites. Man Tech Environmental Resources Services Corporation, Ada, Ok,

[15] Karenlampi, S., Schat, H., Vangronsveld, J., Verkleij, J.A.C., van der Lelie, D., Mergeay, M. and Tervahauta. A. I. (2000). Genetic engineering in the improvement of plants for phytoremediation of metal polluted soils. Environmental Pollution 107: 225-231.

[16] Onyemauche, A.G., Godson, T. F. and Diselph M.B. (2018). Tolerance and bioaccumulation of TPH in Caesalpinia Pulcherrima L and Imperata Cylindrica L. of crude oil contaminated Soils amended with cow dung. American Journal of Earth and Environmental Sciences. 1 (3): 107-114.

[17] Mrozik, A., and Piotrowska-Seget, Z. (2009). Bioaugmentation as a strategy for cleaning up of soils contaminated with aromatic compounds. Microbiological Research, 165:363-375

[18] Eboibi, O., Akpokodje, O. I., and Uguru, H. (2018). Bioremediation of soil contaminated with cassava effluent using organic soap solution. Journal of Environmental Science, Toxicology and Food Technology.12:50-57

[19] Tanee, F. B. G. and Jude, K. (2017). Effect of detergent and sawdust addition on hydrocarbonreduction and growth of Abelmoschus esculentus L (Okra) in a petroleumcontaminated soil. Nig. J. Biotech. 33: 24-33

[20] Okolo, J. C., Amadi, E. N. and Odu, C. T. I. (2005). Effects of soil treatment containing poultry manure on crude oil degradation in sandy loam soil. Appl. Ecol Environ. Res. 3 (1): 47-53.

[21] Ogboghodo, I., Erebor, E., Osemwota, I.O. and Isitekhale, H.H.E. (2004). The effects of application of poultry manure to crude oil polluted soils on maize growth and soil properties. Environ Monit and Assess. 96: 153-161

[22] Onuh M. O., Madukwe D. K. and Ohia G. U. (2008). Effects of poultry manure and cow dung on the physical and chemical properties of crude oil polluted soil, Science World Journal, 3 (2): 1-7

[23] American Public Health Association (APHA), (1995). A Manual on Soxhlet Ext.APHA 5520D

[24] Association of Analytical Communities (AOAC). (1990). Official methods of analysis. 15th Edn. Association Official Analytical Chemists. Washington D.C. 805-845.

[25] Gavrilescu M. (2010) Environmental Biotechnology: Achievements, Opportunities and Challenges. Dynamic Biochemistry, Process Biotechnology and Molecular Biology, 4(1): 1-36. 
[26] Ausma, S,. Edwards, G.C., Fitzgerald-Hubble, C.R., Halfpenny-Mitchell, L.., Gillespie, T.J. and Mortimer, W.P. (2002). Volatile hydrocarbon emissions from a diesel fuel contaminated soil bioremediation facility. Air Waste Manage. Assoc, 52: 769-780.

[27] Ijah, U.J.J. and Safiyanu, H. (1997). Microbial degradation of Escravos light crude oil in soil amended with chicken dropping and NPK fertilizer, 10th Annual Conference of Biotechnology Society of Nigeria

[28] Lee, K., Park, J.W. and Ahn, I.S. (2003). Effect of additional carbon source on naphthalene biodegradation by Pseudomonas putida G7. Journal of Hazardous Materials, 105: 157-167.

[29] Adesodun, J.K. and Mbagwu, J.S.C (2008). Biodegradation of waste lubricating petroleum oil in a tropical alfisol as mediated by animal droppings. Bioresource Technology, 99:5659-5665

[30] Abosede, E.E. (2013). Effect of crude oil pollution on some soil physical properties. J. Agric \& Vet. Sc., 6(3): 14-17.

[31] Udonne, J.D. and Onwuma, H.O. (2014) A study of effects of waste lubricating oil on the physical/chemical properties of soil and the possible remedies. Journal of Petroleum and gas Engineering. 5(1):9-14.

[32] Amadi, A., Dickson, A. and Maate, G.O. (1993). Remediation of oil polluted soils: Effects of organic and inorganic nutrient supplements on the performance of maize. Water, Air and Soil Pollution, 66:59-76.

[33] Palmroth, M. R., Pichtel, J. and Puhakka, J.A (2002). Phytoremediation of subarctic soil contaminated with diesel fuel. Bioresour. Technol. 2002, 84, 221-228.

[34] Ogbo, E.M. (2009). Effect of diesel fuel contamination on seed germination of four crops plants - Arachis hypogea, Vigna unguiculata, Sorghum bicolor and Zea mays. Afri. J. Biotech., (2):250253.

[35] MerkI N, Schutze-Kraft R, and Arias, M. (2005). Influence of fertilizer level on phytoremediation of crude oil contaminated soils with the tropical grass Brachiariabrizantha (Hochst. ex A. Rich.) Stapf. In: Merkl N (Eds). Phytoremediation of Petroleum-contaminated Soil. Margraf Publisher, Weikershim; 71-83

[36] Lee, K., Tremblay, G. H., and Cobanli, S. E (1995). Bioremediation of oil beach sediments: Assessment of inorganic and organic fertilizers. Proceedings of 1995 oil spill conference of American Petroleum Institute, Washington DC. 101-119. 